\title{
FILOSOFÍA Y POESÍA EN HÖLDERLIN
}

\section{PHILOSOPHY AND POETRY IN HÖLDERLIN}

\author{
José Luis GÓMEZ TORÉ \\ gomeztor@terra.es
}

RESUMEN: No puede entenderse la poesía de Hölderlin sin el diálogo que éste establece con la tradición filosófica, en especial con autores como Platón, Spinoza, Kant, Schiller o Fichte. Sin embargo, para el poeta alemán la filosofía acaba mostrando sus insuficiencias frente a la poesía: mientras que la intuición intelectual es inalcanzable por vía racional y filosófica, ésta puede alcanzarse a través de lo estético. Con todo, la propia evolución de la obra del poeta alemán le lleva a éste a cuestionar la posibilidad de que la poesía pueda ser una respuesta definitiva a las escisiones que separan al yo de la naturaleza, de los otros y de sí mismo. En este contexto, cobra una gran importancia el tema del alejamiento de los dioses, que no sólo supone probablemente una versión débil de la muerte de Dios, entre la nostalgia y la espera, sino asimismo una advertencia contra todo intento de encarnar el puesto vacante de la divinidad.

DESCRIPTORES: Hölderlin, estética, intuición intelectual, filosofía de la naturaleza, ausencia de los dioses.

ABSTRACT: Hölderlin's poetry cannot be understood if we forget the poet's dialogue with the philosophical tradition, especially with authors like Plato, Spinoza, Kant, Rousseau, Schiller or Fichte. However, from the point of view of the German poet, philosophy shows, at the end, its limits with poetry by comparison: Intellectual insight cannot be achieved by a rational and philosophical way; it's only possible by a aesthetical way. Nevertheless, the own evolution of this work makes him doubt the possibility of poetry being an ultimate answer to the frontiers which separate the 
self from nature, the self from the others, the self from itself. In this context, the topic of the absence of gods assumes great importance: this is not only a weak version of the Death of God, which is situated between nostalgia and expectancy, but it is furthermore a warning against any intention to incarnate the vacant post of divinity.

KEYWORDS: Hölderlin, aesthetics, poetry, intellectual intuition, philosophy of nature, absence of gods.

Existe desde luego un hospital al que puede retirarse con honor cualquier poeta malogrado como yo: la filosofía. Pero no puedo abandonar a mi primer amor, a las esperanzas de mi juventud, y prefiero caer sin mérito alguno, antes que separarme de la dulce patria de las musas de la que sólo el azar me ha apartado ${ }^{1}$.

Así se refiere Hölderlin a su propio camino intelectual y vital en el que tanto la filosofía como la poesía cumplen un importante papel. La significativa imagen de la filosofía como un "hospital» (que recuerda al De consolatione philosophiae de Boecio) no deja de resultar ambigua: a pesar de tratarse de un retiro honorable, el abandono de la poesía para dedicarse a la filosofía no sería sino el resultado de un fracaso, que permite leer implícitamente la superioridad de lo poético frente a la reflexión filosófica. Sin embargo, la naturaleza autobiográfica del escrito, en el marco íntimo de una comunicación epistolar, podría llevarnos a considerar esta subordinación de la filosofía a la poesía, como algo puramente personal. Como texto aislado, nada nos autoriza a leer esta preferencia como algo más que la certeza de la propia vocación. Sin embargo, lo cierto es que, en el Hiperión, nos encontramos con una afirmación que, sin dejar de reconocer un alto valor a la filosofía, caracteriza a la poesía como origen y fin del pensamiento filosófico. Esta certeza del origen poético de la filosofía evoca probablemente el camino platónico y neoplatónico que conduce desde la Belleza hacia el Bien, hacia la realidad suprema. Pero lo determinante no es esta genealogía del filosofar sino la certeza de que la filosofía no es la culminación de ese saber, sino sólo el paso necesario para una poesía que, enriquecida con la reflexión filosófica, supera sin embargo a ésta como si de un saber superior se tratara (philosophia ancilla poesis, podríamos decir):

${ }^{1}$ Carta a Neuffer del 12 de noviembre de 1798 (F. Hölderlin, Correspondencia completa (1990), p. 388). La cursiva es mía. 
«La poesía, dije seguro de lo que decía, "es el principio y el fin de esa ciencia”. Como Minerva de la cabeza de Júpiter, mana esa ciencia de la poesía de un ser infinitamente divino. Y así confluye al fin también en ello lo que hay de incompatible en la misteriosa fuente de la poesía ${ }^{2}$.

[...] De la pura razón no ha surgido ninguna filosofía, pues filosofía es más que ciega exigencia de un progreso nunca demasiado resolutivo en el arte de unir y de diferenciar una determinada sustancia ${ }^{3}$.

Hay así, en este proceso, algo semejante a la Aufhebung hegeliana. La más alta poesía supone una superación de la filosofía que no niega a ésta sino que la integra convirtiendo el filosofar en un elemento imprescindible del despliegue espiritual del saber poético aunque supeditado a éste. Desde luego, la filosofía forma parte imprescindible de la autocomprensión intelectual de Hölderlin ${ }^{4} \mathrm{y}$ no es de extrañar que, desde su redescubrimiento en los inicios del siglo XX, haya despertado la atención no sólo de poetas sino también de filósofos como Heidegger, Gadamer, Adorno o María Zambrano. La intensa escritura del poeta suabo, que compartió habitación en el Seminario (el Stift) de Tubinga con Schelling y con Hegel, con los que parece compartir asimismo la autoría del llamado «el más antiguo programa de sistema del idealismo alemán»" no puede entenderse sin sus múltiples lecturas filosóficas. Precisamente en el programa que probablemente escribió con Schelling y Hegel, encontramos una defensa de la integración entre filosofía y poesía que recuerda al ya citado texto de Hiperión:

[...] la verdad y el bien sólo en la belleza están hermanados. El filósofo tiene que poseer tanta fuerza estética como el poeta. [...]

La poesía recibe de este modo una más alta dignidad, vuelve a ser al final lo que era al principio - maestra de la humanidad—, pues ya no hay filosofía, ya no hay historia, sólo la poesía sobrevivirá a todas las demás ciencias y artes ${ }^{6}$.

2 F. Hölderlin, Hiperión (1998), p. 115.

Id., p. 118.

${ }^{4}$ Vid. A. Ferrer, Hölderlin (2004), pp. 51-66.

5 Aunque, como parece, Schelling haya sido el redactor definitivo del texto, las ideas que aparecen en él provienen no sólo de éste sino también de Hegel y, probablemente, sobre todo, de Hölderlin (Cf. F. Martínez Marzoa, introducción a F. Hölderlin, Ensayos (2001), p. 10).

${ }^{6}$ F. Hölderlin, Ensayos (2001), p. 30. Cf. H. Cortés Gabaudan, Claves para una lectura de Hiperión (1996), p. 240). 
Hölderlin, que, en su juventud, parecía destinado, por voluntad materna, a convertirse en pastor protestante, encontró en la lectura de autores como Spinoza, Fichte, Rousseau o Kant una salida al dogmatismo religioso que impregnaba la educación del Stift. Por alejada que pueda estar la visión de lo divino en Hölderlin del rigorismo ético kantiano o del racionalismo spinozista, la lectura de estos autores le abrió el camino al poeta para iniciar una búsqueda de lo sagrado que no tuviera que someterse a dogmas previos. Asimismo, para los jóvenes Hegel, Hölderling, Schelling (sea o no cierto el célebre episodio del Árbol de la Libertad $^{7}$ ), la libertad de la razón, su emancipación del dogmatismo, se correspondía con el deseo de una libertad política, de un pueblo también emancipado, asimismo elevado a la mayoría de edad. Como dirá el Hölderlin más maduro del Empédocles, ya casi a las puertas de la locura: «Ya no es tiempo de reyes» ${ }^{8}$.

Si a la postre su pensamiento le va a llevar a una subordinación de la filosofía respecto de la poesía, lo cierto es que, aun en los momentos que Hölderlin se muestra más crítico con la tradición filosófica, su escritura literaria debe mucho al diálogo (que, a menudo, es confrontación) con la filosofía. Si hay en el poeta una aspiración constante a integrarse en la naturaleza, Hölderlin sabe que dicha reconciliación no es algo ya dado, sino fruto de un penoso esfuerzo. Como lector de Schiller, el poeta no puede sino conocer la diferencia que éste establecía entre poesía ingenua y poesía sentimental: para Schiller, poeta ingenuo es aquel que parte de una cercanía, de una distancia mínima con la naturaleza mientras que el poeta sentimental no puede escribir sino desde la conciencia que le separa del mundo natural: «El poeta, he dicho, o es naturaleza o la buscará; de lo uno resulta el poeta ingenuo, de lo otro el sentimental» ${ }^{9}$. No se trata, sin embargo, de una elección: nadie puede ser, por voluntad propia, poeta ingenuo. En este sentido, el poeta no puede escapar a los condicionamientos de su época y de su cultura. Cuando la cultura nos ha arrancado del estado natural, no hay posibilidad de vuelta atrás. El que intenta desandar la senda que le ha llevado al actual

${ }^{7}$ Este episodio, en el que se supone que participaron Schelling, Hegel y Hölderlin, deja bien a las claras el entusiasmo que en los tres jóvenes despertó inicialmente la Revolución Francesa (si bien los especialistas últimamente dudan de la veracidad de este suceso como señala Helena Cortés Gabaudan —Claves para una lectura de Hiperión (1996), pp. 141-142)—. Cf. R. Argullol, El Héroe y el Único (2008), p. 57.

8 F. Hölderlin, Empédocles (1997, p. 163).

9 F. Schiller, Sobre Poesía Ingenua y Poesía sentimental (1994), p. 28. 
estado de autoconciencia racional sólo puede convertirse en un bárbaro o en un impostor. Se trata de retornar a la naturaleza, pero sin buscar atajos fáciles y paradójicamente avanzando hacia delante, por la senda de la cultura, con la confianza de que, en algún momento, el camino acabará por llevarnos al lugar donde partimos (aunque no exactamente al lugar de donde partimos, porque el reencuentro con la naturaleza no se producirá desde la inconsciencia del primitivo o del niño, sino desde la máxima conciencia, desde una reconciliación entre la razón y la naturaleza): «Hemos sido naturaleza [...] y nuestra cultura debe volvernos, por el camino de la razón y de la libertad, a la naturaleza» ${ }^{10}$. Hölderlin se expresa en términos parecidos en el prólogo del Fragmento de Hiperión publicado en la revista Talía, un texto del Fragmento que, como señalan Carlos Durán y Daniel Innerarity expresa «un carácter terapéutico: una conversión a la finitud, a la tierra con sus alegrías y tristezas» ${ }^{11}$, después del optimismo ingenuo y juvenil de los Himnos de Tubinga:

Hay dos ideales de nuestra existencia: un estado de suprema inocencia, donde nuestras necesidades concuerdan recíprocamente consigo mismas [...] gracias a la simple organización de la naturaleza, sin nuestra intervención, y un estado de suprema cultura, donde ocurriría lo mismo con respecto a necesidades y fuerzas infinitamente multiplicadas e intensificadas, gracias a la organización que nosotros mismos somos capaces de darnos. La órbita excéntrica, que el hombre, en comunidad y en solitario, recorre desde un punto (el de la inocencia más o menos pura) hasta otro (el de la cultura más o menos consumada) parece ser, según sus direcciones esenciales, siempre igual a sí misma ${ }^{12}$.

Hölderlin dibuja aquí un itinerario que es a la vez individual y colectivo, el sendero que se le abre en perspectiva a todo hombre que quiera tomarse en serio su existencia y a toda sociedad que se interrogue sobre sí misma. La metáfora que

${ }^{10}$ F. Schiller, op. cit., p. 3 (la cursiva es mía). Una idea muy semejante la encontramos en las Cartas sobre la educación estética del hombre, donde se defiende que todos los pueblos «sin excepción, han de alejarse al principio de la naturaleza, guiándose por razonamientos equívocos, antes de ser capaces de regresar a ella por medio de la razón» (Schiller (1990), p. 143). Probablemente, Heinrich von Kleist tiene muy presentes estos textos cuando escribe en una época posterior: «[...] tenemos que volver a comer del Árbol del Conocimiento para recobrar el estado de inocencia» (Sobre el teatro de marionetas y otros ensayos de arte y filosofía (1988), p. 36).

${ }^{11}$ Introducción a F. Hölderlin, Los himnos de Tubinga (2005), p. 36.

12 Los himnos de Tubinga, ed. cit., p. 149. 
utiliza, procedente de la astronomía ${ }^{13}$, resulta especialmente significativa, ya que, mientras que la órbita sugiere la idea de un retorno, el hecho de que sea excéntrica nos hace intuir que el peligro de perderse es máximo, pues existe una fuerza centrífuga que aleja al hombre de su meta. La necesaria toma de conciencia puede llevarnos demasiado lejos hasta el punto de cortar todo contacto entre razón y naturaleza. Este camino de ida y vuelta entre naturaleza y cultura hay que entenderlo en correspondencia con el camino de ida y vuelta que establece entre filosofía y poesía. Para expresarlo en términos schillerianos, podríamos decir que se trata de ir de una conciencia ingenua poética (de comunión inicial con la naturaleza) para, tras pasar por el distanciamiento máximo que supone la razón analítica y por la doble aproximación de una síntesis racional y una poesía sentimental, volver a reencontrarse con el Todo a través de una síntesis que ya no se deja expresar en las categorías de la razón. Para Hölderlin, sólo el arte es capaz de reunir en una unidad los contrarios, esa unión que había presentido Heráclito ${ }^{14}$. La poesía ha necesitado dialogar con la filosofía en las etapas intermedias del camino pero el último tramo debe hacerlo sola ${ }^{15}$. Para comprender por qué llega Hölderlin a esta conclusión, tenemos que aproximarnos a la doble cuestión del conocimiento y la naturaleza.

\section{Los límites del conocimiento racional y la belleza como camino hacia el uno}

El conocimiento racional aspira siempre a una síntesis explicativa. La razón debe descomponer analíticamente la realidad, pero si divide lo real, dicha división no tiene otro objeto que volver a unir, que acceder a una comprensión global. Hölderlin no ignora ese momento de síntesis de la razón. Sin embargo, le resulta insuficiente. Ningún esfuerzo filosófico puede saltar el abismo que se establece entre el sujeto que conoce y lo conocido. Para decirlo con el mito del Génesis (cuyo simbolismo probablemente deja su huella en Hölderlin), podríamos decir que, una vez que se ha comido del fruto del árbol de la ciencia, no es posi-

${ }^{13}$ Vid. A. Ferrer, Hölderlin (2004), p. 72.

${ }^{14}$ Cf. Hiperión (1998), p. 116.

${ }^{15}$ Como explica Salvador Mas, en Hölderlin se produce una radicalización que «supone pasar de la insuficiencia de... (Fichte, Spinoza o Schelling) a la insuficiencia del discurso filosófico en cuanto tal» (Hölderlin y los griegos (1999), p. 67, 
ble el retorno al paraíso de la indistinción originaria entre el yo y la naturaleza. Precisamente en la división entre la conciencia y lo que es objeto de la conciencia fundará Hölderlin su temprana crítica al Yo absoluto de Fichte. En efecto, para el poeta, no cabe hablar de un Yo absoluto ya que, en su opinión, supondría una conciencia sin objeto, lo cual implica una contradicción, tal como señala en una carta dirigida a Hegel el 26 de enero de 1795:

Las hojas especulativas de Fichte —el Fundamento de toda la Doctrina de la ciencia-, así como sus lecciones impresas acerca de la condición del sabio, te interesarán mucho. Al principio, tenía bastantes sospechas de que pecase de dogmatismo [...] su Yo absoluto (=la substancia de Spinoza) contiene toda realidad [...] pero una conciencia sin objeto no es pensable, y si resulta que soy yo mismo ese objeto, estoy como tal necesariamente limitado, aunque sólo sea en el tiempo, luego no soy absoluto; por lo tanto no es pensable ningún tipo de conciencia en el Yo absoluto $[\ldots]^{16}$

La identificación del Yo absoluto con la sustancia de Spinoza ciertamente resulta poco atinada. Hölderlin parece pensar el Yo fichteano como sustancia, no como actividad. En la filosofía de Fichte, el Yo como primer principio no borra la existencia del no-Yo, sino que, por el contrario, la autoconciencia está siempre unida con el conocimiento de lo otro como otro. En palabras de Jacinto Rivera de Rosales, «la absolutez del Yo fichteano no es óntica sino ontológica» ${ }^{17}$. El Yo fichteano es acción que se abre a la comprensión de toda la realidad pero no es toda la realidad. "Hölderlin malinterpreta la enseñanza de Fichte Sobre el «"Yo absoluto" " ${ }^{18}$, pero el hecho de establecer una vinculación con la sustancia spinozista es significativo. Hölderlin atribuye a Fichte lo que no es sino su propio deseo: encontrar una vía de acceso al Todo, la naturaleza como lo divino inmanente. La sustancia spinozista identificada con lo divino es causa de lo racional pero no son atributos divinos ni el conocimiento ni la voluntad ${ }^{19}$. Si bien Höl-

16 Correspondencia completa (1990), p. 232.

17 «El primer principio en Fichte» (1996), p. 79.

${ }_{18}$ Uwe Beyer, Mythologie und Vernunft (1993), p. 22 (la traducción es mía).

19 Como se afirma en la Proposición XXXI de la Parte I de la Ética: «El entendimiento en acto, sea finito o infinito, así como la voluntad, el deseo, el amor, etc., deben ser referidos a la Naturaleza naturada, y no a la naturante» (Spinoza, op. cit. (2006), p. 85. Sobre la importancia de Spinoza en la Alemania de Hölderlin y la disputa entre una interpretación panteísta o una interpretación ateísta del filósofo, véase H. Cortés, Claves para una lectura de Hiperión (1996), pp. 40-51. 
derlin muestra en este texto sus reservas tanto hacia Spinoza como hacia Fichte, lo cierto es que implícitamente su reflexión considera más razonable la hipótesis spinozista de un Absoluto impersonal (ni consciente ni autoconsciente ${ }^{20}$ ) que el Yo absoluto que atribuye a Fichte (como insiste Hölderlin, es inconcebible un Yo que no sea al mismo tiempo conciencia y autoconciencia, es decir, separación del yo frente al no-yo y separación del yo frente a sí mismo $^{21}$ ).

Hölderlin juega con la supuesta etimología de la palabra alemana Urteil («juicio»), vinculada con el verbo teilen («separar») y que el poeta asocia asimismo al prefijo $U r$-, que en alemán tiene siempre el sentido de lo originario, de lo primitivo. De esta manera, Urteil se convierte en Ur-teilung, separación originaria entre el sujeto que conoce y el objeto de su juicio ${ }^{22}$. La razón no puede, por tanto, destruir la distinción entre sujeto y objeto sin negarse a sí misma. Hay, en todo caso, una aproximación infinita como aspiración a la totalidad, que puede acercarnos a lo Uno pero sin que quepa, por una vía estrictamente racional, llegar a una completa reconciliación. Por otra parte, la lectura de Kant (a quien llama, en una carta, «el Moisés de nuestra nación ${ }^{23}$ ) le había enseñado a Hölderlin los límites de la razón, que no puede acceder a la cosa en sí: nos es posible conocer sólo la realidad fenoménica a través de un a priori puesto, en el acto del conocimiento, por el sujeto trascendental. Lo nouménico, lo real en sí, sólo nos es dado pensarlo.

Aunque la respuesta de Hölderlin no es en absoluto kantiana, su planteamiento del problema no deja de lado las serias advertencias de Kant aunque éstas se toman en un sentido que al filósofo de Königsberg no dejarían de causarle estupefacción. El camino lo había abierto Schiller, quien en sus Cartas sobre la educación estética del hombre defiende que el arte nos permite experimentar que no hay incompatibilidad entre la necesidad que parece regir la naturaleza y la libertad que exige nuestra realidad como seres morales, una idea de libertad que,

${ }^{20}$ En una de las versiones previas del Hiperión, la versión métrica escrita entre 1794 y 1795 , Hölderlin plantea la existencia de un principio divino impersonal: «El espíritu puro y libre de pasiones no se ocupa/ de la materia, pero tampoco es consciente/ ni de un solo asunto, siquiera de los suyos" (Hiperión. Versiones previas (1989), p. 79).

${ }_{21}^{21}$ "Vid. «Juicio y ser», Ensayos (2001), p. 28).

22 «Juicio y ser», art. cit. (2001), p. 27.

${ }^{23}$ Carta al hermano del 1 de enero de 1799 (Correspondencia completa (1990), p. 405). 
para Kant, hay que considerar un postulado de la razón práctica pero que, como tal, no puede ser objeto de conocimiento. En dichas Cartas, Schiller afirma: «iPor qué cada uno de los griegos puede erigirse en representante de su tiempo, y no así el hombre moderno? Porque al primero le dio forma la naturaleza, que todo lo une, y al segundo el entendimiento que todo lo divide» ${ }^{24}$. La naturaleza se presenta como guía para superar las escisiones a las que aboca la conciencia. Schiller, que en lo posible intenta mantenerse dentro de los límites establecidos por Kant, va más allá de éste al considerar que la educación estética nos ofrece un camino para experimentar el juego mutuo de libertad y necesidad que constituiría la verdadera realidad del hombre y el mundo. Tanto a Schiller como a Hölderlin les sirve de acicate el análisis kantiano de lo sublime, en su formulación más madura, la presente en la Crítica del juicio. En dicha obra, Kant señala que el sentimiento de lo sublime nos conmueve porque despierta en nosotros la idea de lo real en sí: al evocar dicha idea, se nos recuerda que, en el acto de conocer, «no tratamos más que con una naturaleza como fenómeno, y que esta misma hay que considerarla como mera exposición de una naturaleza en sí (que la razón tiene en la idea) ${ }^{25}$. En la experiencia de lo sublime se nos hace presente la idea de una realidad en sí más allá de nuestra percepción y de nuestro entendimiento. Sin embargo, Kant se muestra taxativo: no puede hablarse de un conocimiento estético de lo bello ni de lo sublime ya que «una idea estética no puede llegar a ser un conocimiento» ${ }^{26}$.

Aunque sin duda en Kant (como en su antecesor Edmund Burke) resulta fundamental la distinción entre lo bello y lo sublime, no se puede hablar propiamente en Hölderlin de una separación. En la estética hölderliniana se consuma la indistinción entre lo bello y lo sublime que había empezado a insinuarse en Schiller ${ }^{27}$. Más que separación al modo kantiano nos encontramos con una gradación de inspiración platónica y neoplatónica: la belleza es siempre una aspiración hacia lo sublime, ya que en toda experiencia de belleza se insinúa un camino de reencuentro con la totalidad perdida. Como en el Platón del Banquete

${ }^{24}$ Cartas sobre la educación estética del hombre (1990), p. 145 (la cursiva es mía).

${ }^{25}$ I. Kant, Crítica del juicio (1984), p. 171.

${ }^{26}$ Id., p. 250.

27 Jaime Feijóo defiende «la más o menos manifiesta identidad de lo bello y lo sublime en el concepto de belleza de Schiller» (introducción a las Cartas sobre la educación estética del hombre (1990), p. XXXVII). 
(cuya Diótima es una fuente de inspiración evidente del personaje femenino del mismo nombre en el Hiperión), la belleza nos permite ascender hacia la realidad superior:

[...] intento desarrollar la idea de un progreso infinito de la filosofía, intento mostrar que la exigencia inevitable que hay que plantearle a cada sistema, la reunión del sujeto con el objeto en un absoluto - Yo, o como se le quiera denominar- es posible estéticamente en la intuición intelectual, pero que teóricamente sólo lo es mediante una infinita aproximación $[\ldots]^{28}$

El pensamiento se topa siempre con un límite infranqueable. Sin embargo, lo que no nos es dado en la aproximación asintótica del pensamiento a lo real, podemos intuirlo estéticamente mediante el arte. He aquí por qué la filosofía debe, en última instancia, reconocer a la poesía como maestra: la Totalidad como tal es incognoscible pero es experimentable estética, poéticamente. El pensamiento nos muestra la naturaleza como lo otro; en el arte podemos experimentar la unión de lo sensible con lo ideal, de lo individual con lo universal. Claro que, si se acepta esto, estamos ya muy lejos de Kant, quien negó taxativamente la posibilidad de una intuición intelectual (y también de Fichte, cuyo concepto de intuición intelectual no supone el conocimiento de la cosa en sí).

En este terreno, Hölderlin se muestra, como en su idea de la Belleza, más platónico que kantiano. Sin embargo, la relación que se establece en su pensamiento entre el conocimiento discursivo y la intuición intelectual revela una importante diferencia con Platón (quien, por otra parte, acabará, como se sabe, condenando la poesía como una actividad engañosa). Para Platón, la relación entre conocimiento discursivo e intuición es una relación ascendente ${ }^{29}$ : la mente del filósofo puede ir ascendiendo, por diversos grados de conocimiento, de la dianoia a la noiesis, y una vez alcanzada ésta, es posible asimismo un camino descendente desde la contemplación de las Ideas al mundo sensible. Para Hölderlin, sin embargo, no se trata de una ascensión constante. En un momento determinado, hay que saltar, porque hay un abismo infranqueable entre el pensamiento discursivo y la intuición intelectual. Ahí la poesía, que hasta entonces podía ser

${ }^{28}$ Carta a Schiller del 4 de septiembre de 1795 (Correspondencia completa (1990), p. 263.)

${ }^{29}$ Recuérdese, al respecto la alegoría de la línea en la República (1992), libro VI, XX-XXI, pp. $362-367$. 
compañera de la filosofía, se queda sola: únicamente la intuición poética puede dar el salto, salvar el abismo y acceder a la experiencia de la totalidad. Hasta ese momento, el poeta se ha podido servir de la filosofía como un apoyo, como una escalera en su ascensión. Pero en el último tramo hay que tirar la escalera. Sólo dando el salto, puede el poeta retornar a la naturaleza entendida como lo divino inmanente en un sentido más próximo al neoplatonismo que a Spinoza.

Esta reintegración de la naturaleza la expresa míticamente el poeta en la contraposición entre Júpiter y Saturno en el poema titulado precisamente «Naturaleza y Arte o Saturno o Júpiter» ${ }^{30}$. El dios Júpiter se nos muestra como el símbolo de la división introducida por la cultura, de una razón que intenta hacer de la naturaleza su esclava y, a la postre, también intenta convertir en instrumento a los seres humanos. Para que la razón deje de ser lo que nos separa de la naturaleza, Júpiter debe reconciliarse con su padre Saturno, el desterrado. Júpiter, no obstante, no ha alcanzado su dominio sólo por un acto de violencia. No es sólo un dios del poder: en el poema aparece también como un dios civilizador, como el legislador que da normas a los hombres y al mundo. Por ello, aunque se aspire al regreso de la Edad de Oro, del reino de Saturno, ello no supone borrar lo que de bienhechora tiene la acción racional de Júpiter. El poeta no proclama la venganza de Saturno y la abolición del reino de Júpiter, sino su reconciliación. Saturno, en el estado inicial, es un dios que carece de nombre y que no dicta leyes. Es la suprema unidad de todo, pero también la suprema inconsciencia (como se dice en la versión inacabada del Hiperión de Jena de 1795, «él lo es todo, y por eso no es nada para sí mismo. No carece de nada, porque es incapaz de desear; no sufre, pues no vive» ${ }^{31}$ ). El abrazo entre Saturno y Júpiter (simbolizado en el nuevo nombre que se otorga a éste al final del poema, "Cronión", hijo de Cronos/Saturno) supone una reconciliación entre la naturaleza y la cultura. Las leyes de Júpiter/Cronion no serán leyes enemigas de la naturaleza, porque el hombre se ha hecho consciente de su origen y ha hecho a la naturaleza así autoconsciente. El retorno a la naturaleza no implica por tanto una renuncia a la cultura (al igual que en Rousseau, una de las referencias fundamentales para Hölderlin, la idealización del estado natural, presente en el Discurso sobre el origen y los fundamentos de la desigualdad entre los hombres no lleva en El contrato social a

30 Odas (1999), pp. 146-149.

31 Hiperión. Versiones previas (1989), p. 100. 
la propuesta de abolición de toda sociedad, sino a una reflexión que parte ya de una inevitable organización política de la vida en común). El poeta siente que su papel no es otro que colaborar en la llegada de esa nueva época, en la que se hermanan naturaleza y cultura. Para él la unión entre razón y naturaleza no es imposible, porque está firmemente convencido de que esa reconciliación se dio en Grecia. Siguiendo la ya conocida metáfora de la órbita excéntrica, Hölderlin describe una evolución de la cultura griega que abraza lo racional pero que, sin embargo, parte de un impulso mítico, irracional, que es el que les sería propio ${ }^{32}$. Hölderlin, en polémica implícita con el clasicismo, considera que lo propio de los griegos es lo que Nietzsche llamaría lo dionisíaco ${ }^{33}$ (y que, en la «Carta a Böhlendorf", sin embargo, se identifica con Apolo). Si en los griegos el predominio de lo irracional les llevó a buscar la serenidad racional simbolizada por Juno, la civilización moderna, dominada por la razón, deberá hacer el camino contrario y reencontrarse con aquello que en la naturaleza es irreductible a la razón. Esta conciliación entre naturaleza y razón no se produce sin conflictos. De hecho en ocasiones Hölderlin parece arrojar una condena absoluta sobre lo racional ( ${ }_{i} \mathrm{Oja}$ lá no hubiera ido nunca a vuestras escuelas! [...] En vuestras escuelas es donde me volví tan razonable, donde aprendí a diferenciarme de manera fundamental de lo que me rodea») ${ }^{34}$. Sin embargo, pesa más en Hölderlin la convicción de que la separación mediante la razón es un momento esencial del camino de retorno a la naturaleza, y aunque es la experiencia suprarracional del arte la que tiene la última palabra, la experiencia estética ha necesitado el antagonismo de la razón para encontrar su forma más acabada.

Salta a la vista de nuevo la cercanía con la dialéctica hegeliana ${ }^{35}$ : de una oposición entre dos elementos en apariencia antitéticos, surge una unidad, una reconciliación que los supera incluyéndolos. Existe también una afinidad en el hecho de que, para ambos, la temporalidad desempeñe un papel esencial. En Hegel el proceso de manifestación del Espíritu se despliega en la historia, la verdad se va

32 Carta a Böhlendorf (Ensayos (2001), p. 138).

33 Gadamer considera a Hölderlin «el precursor del descubrimiento nietzscheano del sustrato dionisíaco de lo apolíneo en la cultura griega» («La actualidad de Hölderlin» (1999), p. 11). Sobre lo dionisíaco en Hölderlin, véase H. Cortés, Claves para una lectura de Hiperión (1996), pp. 199-233.

34 Hiperión (1998), p. 26.

35 Aunque plantea una relación desde otro punto de vista, resulta interesante el libro de Felipe Martínez Marzoa Hölderlin y la lógica hegeliana (1995). 
revelando a través de un proceso; Hölderlin, por su parte, sabe que fue preciso abandonar el seno de la naturaleza, alejarse de ella, para encontrarse con ella. La temporalidad que nos aleja de lo eterno es a la vez el lugar de encuentro: cuando «en su cuna el tiempo cambiante / se adormezca de gozo» ${ }^{36}$, desaparecerá el desgarramiento de una temporalidad que aboca siempre al cambio y a la muerte y se ofrecerá a los ojos de los mortales una reconciliación entre tiempo y eternidad, porque sólo a través del despliegue de la temporalidad se ha producido el reencuentro con lo que siempre es. No obstante, hay una diferencia esencial entre Hegel y Hölderlin (y que tiene que ver con la prioridad que uno da a la filosofía y el otro a la poesía): en vano buscaremos en Hölderlin una identificación entre lo racional y lo real. La razón es, por el contrario, para el poeta, un momento de la verdad, pero no el único. Hay un fondo indisponible en lo real al que no podemos acceder racionalmente pero que Hölderlin (antes que la escisión trágica se imponga en su conciencia) cree que podemos experimentar en la obra de arte.

$\mathrm{Al}$ igual que Platón consideraba la filosofía como un valor terapéutico capaz de curar los males del alma y de la sociedad, Hölderlin, en esto muy cercano a Schiller, se plantea el poder terapéutico del arte, capaz de hacer volver a los seres humanos al seno de la naturaleza, desde la confianza en que la violencia y los conflictos que amenazan toda sociedad humana puedan ser superados: «Como riñas de los amantes son las disonancias del mundo. En la disputa está latente la reconciliación., y todo lo que se separa vuelve a encontrarse» ${ }^{37}$.

La labor educadora de la filosofía resulta insuficiente, porque la razón, a pesar de su voluntad sintetizadora, no puede abrazar la totalidad porque ella misma es división. De ahí que, ante un yo escindido y una sociedad fragmentada, se proponga la figura del poeta como educador.

\section{Hiperión: el poeta como educador}

Las Cartas sobre la educación estética del hombre fue una obra determinante para Hölderlin, probablemente porque ofrecía una posible conciliación entre sus

\footnotetext{
${ }^{36}$ F. Hölderlin, «Naturaleza y Arte o Saturno y Júpiter», Odas (1999), p. 147.

37 Hiperión (1998), p. 213.
} 
inquietudes filosóficas y su cada vez más clara vocación poética. A la admiración que sentía por el Schiller literato se unía la habilidad de éste para, apoyándose en la filosofía de Kant, intentar superar la antinomia kantiana entre libertad y necesidad no mediante un postulado de la razón sino por la experiencia de la obra de arte. Da fe de la importancia que para Hölderlin tuvieron las Cartas el hecho de que incluso proyectara la escritura de una obra semejante:

En las cartas filosóficas quiero encontrar el principio que me explique las escisiones en las que pensamos y existimos, pero que también sea capaz de hacer desaparecer el antagonismo entre el sujeto y el objeto, entre nuestro yo y el mundo, esto es, también entre razón y revelación, de modo teórico, en la intuición intelectual, sin tener que recabar ayuda de nuestra razón práctica. Para ello precisamos de sentido estético, y llamaré a mis cartas filosóficas Nuevas cartas sobre la educación estética del hombre ${ }^{38}$.

En la convicción de que es posible una «intuición intelectual» y en el propósito de no «recabar ayuda de nuestra razón práctica», resulta evidente la intención de Hölderlin de partir de Kant para ir más allá de Kant con ayuda de Schiller. Aunque Hölderlin nunca remató el proyecto de las Nuevas cartas, escribió Hiperión, que, como veremos, es no sólo una defensa de la educación estética sino educación estética en sí misma. No hay que olvidar que, en Schiller, la educación estética es un intento de responder no sólo a cuestiones éticas sino también políticas: no se trata sólo de hacer moral al hombre, sino de moralizar la convivencia entre los seres humanos (en el horizonte ideal de un Estado estético que reconciliara la coacción de las leyes morales y políticas con la libertad de los ciudadanos). Para leer en profundidad tanto las Cartas de Schiller como el Hiperión de Hölderlin, conviene no olvidar que ambas son obras escritas desde el desengaño ante la deriva de la Revolución Francesa hacia el Terror. La serenidad de las Cartas en contraste con el dramatismo del Hiperión no deben ocultarnos que, a pesar de la diferencia del tono y de la exposición, en ambas obras se muestra la pregunta de si es posible cambiar a la sociedad sin cambiar a los hombres que la forman, si es posible un cambio político sin un profundo cambio moral.

${ }^{38}$ Carta del 24 de febrero de 1796 a Immanuel Niethammer (Correspondencia completa (1990), p. 289). 
El año en que aparecen las primeras Cartas de Schiller, 1795, es el año en que probablemente se redacte «El más antiguo programa de sistema del idealismo alemán»:

[...] tenemos que tener una nueva mitología, pero esta mitología tiene que estar al servicio de las ideas, tiene que llegar a ser una mitología de la Razón.

Mientras no hagamos estéticas, mitológicas, las ideas, ningún interés tienen para el pueblo, e inversamente: mientras la mitología no sea racional, el filósofo tiene avergonzarse de ella [...] la mitología tiene que hacerse filosófica para hacer racional al pueblo, y la filosofía tiene que hacerse mitológica para hacer sensibles a los filósofos ${ }^{39}$.

Los tres redactores del documento (si en efecto son, como se cree, Schelling, Hölderlin y Hegel) desconfían de que la sola argumentación racional de una minoría ilustrada pueda cambiar la sociedad. De manera tácita en Schiller, de manera explícita en los redactores del programa, nos encontramos aquí con una crítica de una de las convicciones más arraigadas de la Ilustración. En otras palabras, se trata de preguntarse si es posible conseguir la libertad y la igualdad sin fraternidad. Hölderlin, como sus compañeros de habitación, probablemente había leído en Spinoza que «las imaginaciones no se desvanecen ante la presencia de lo verdadero, sino porque se presentan otras imaginaciones más fuertes» ${ }^{40}$. Y, sin duda, Hölderlin estaría de acuerdo con Rousseau cuando afirmaba que «digan lo que digan los Moralistas, el entendimiento humano le debe mucho a las Pasiones, que según la opinión común también le debe mucho a aquel. Es a través de su actividad que nuestra razón se perfecciona» ${ }^{41}$. Frente a la pretensión

39 F. Hölderlin, Ensayos (2001), p. 31.

${ }^{40}$ Ética (2006), p. 291. La lectura de Spinoza por parte del joven Hölderlin queda patente tanto en su ensayo "Las cartas de Jacobi sobre la doctrina de Spinoza» como por su correspondencia: así, por ejemplo, la carta que el joven Hölderlin dirige a su madre en 1791: "Por aquel tiempo me cayeron entre las manos escritos sobre o de Spinoza, un hombre grande y noble del siglo pasado, y con todo, ateo si nos atenemos a conceptos estrictos» (Friedrich Hölderlin, Correspondencia completa (1990) pp. 115-116). Unos años después, en 1800, aparecerá la primera parte de la Conversación sobre la poesía de Friedrich Schlegel, en la que se afirma «es casi incomprensible cómo se puede ser poeta sin honrar a Spinoza, sin amarlo y sin ser de los suyos» (op. cit. (2005), p. 65)

${ }^{41}$ Discurso sobre el origen y los fundamentos... (1970), p. 48. 
kantiana de una ley moral que se basta a sí misma, sin la ayuda de ninguna otra motivación (única garantía, en su opinión, de que no estamos ante una moral heterónoma), los redactores del programa no creen que la racionalidad baste para definir lo esencial humano. Sin embargo, Hölderlin irá más allá de la constatación de que el hombre es un ser tanto pasional como racional y por tanto, la sola razón no basta para persuadirle si no va acompañada de la fuerza de la imaginación. No se trata sólo de que la razón deba vestirse con las armas de la persuasión retórica. No se trata sólo de convencer. Para Hölderlin, la educación estética no es un recurso pedagógico, sino un valor en sí mismo: el progreso espiritual no consiste únicamente en ser cada vez más racionales sino también, y sobre todo, en hacernos, si se me permite la expresión, poéticos, convertir la propia vida en una obra de arte en contacto con la naturaleza. Esta educación estética no supone, sin embargo, un camino individual. Tiene, como en Schiller, una dimensión colectiva.

En sus juveniles Himnos de Tubinga, en los que la Revolución es todavía un sueño posible y cercano, Hölderlin se muestra ya convencido de la existencia de una oculta correspondencia entre la naturaleza y el mundo humano. Existe una constelación simbólica que vincula tres planos: el cósmico (la Armonía como divinidad rectora de la naturaleza), el político (el sentimiento revolucionario de fraternidad) y el más íntimo (la amistad). En el fondo, constituyen tres facetas de lo mismo: una reconciliación que se quiere universal y que trasciende el plano estrictamente personal. La Revolución no es sólo política aunque también es política. El abandono posterior del tono demasiado exaltado de los himnos se debe, indudablemente, a razones literarias de peso: el poeta comprende que el artista no alcanza lo sublime sólo con pretenderlo, que no basta el entusiasmo y que, antes que elevarse demasiado alto y conquistar la ligereza, su voz tiene que cargarse primero con el peso del mundo. Pero en Hölderlin difícilmente puede hablarse de una razón estrictamente literaria: si la poesía importa, si es ésta una cuestión vital y no un adorno o pasatiempo, la exigencia literaria implica abrir, por la palabra, un camino hacia lo real. Las limitaciones de su primera escritura, los desengaños personales, la desilusión ante la evolución posterior de la Revolución, llevan a Hölderlin a constatar que se precipitó tanto en la certeza de una paz perpetua como en la seguridad de una cercana reconciliación con la naturaleza. Antes que llegar a la armonía, hay que pasar por la experiencia de la separación. La reconciliación no está dada, sino que es fruto de una dolorosa conquista. Como señala Octavio Paz, Hiperión tiene una doble dimensión: 
El tema de Hiperión es doble: el amor por Diótima y la fundación de una comunidad de hombres libres. Ambos actos son inseparables. El punto de unión entre el amor a Diótima y el amor a la libertad es la poesía. Hiperión no sólo lucha por la libertad de Grecia sino por la instauración de una sociedad libre; la construcción de esta comunidad futura implica asimismo un regreso a la poesía ${ }^{42}$.

Mediante la poesía, Hölderlin, pretende crear los lazos de fraternidad que vinculen la libertad y la igualdad como germen de una sociedad libre. Existe una correspondencia secreta entre el amor a Diótima, la amistad con Alabanda y el deseo de libertad. Una correspondencia que pareciera querer conciliar en una unidad superior el eros y el ágape, el paganismo de exaltación de la naturaleza y un cristianismo sin dogmas, un cristianismo paganizado, en el que Cristo es sólo uno de los rostros posibles de lo divino, no el intérprete único y definitivo de lo sagrado. En una de sus odas de madurez, «El amor», Hölderlin plantea expresamente el deseo de que «el lenguaje / de los amantes sea la lengua de la tierra! / ${ }_{i} \mathrm{Y}$ sea su alma la voz del pueblo!» ${ }^{43}$. Es el sueño de un amor que es a la vez eros, fraternidad y comunión con la tierra. El amor se revela entonces como una utopía personal y como el presentimiento de una utopía futura.

Puede sorprender que la naturaleza sea, para Hölderlin, una guía no sólo para la igualdad de los seres humanos sino también para sus ansias de libertad. ¿No es acaso la naturaleza el reino de la necesidad? Para Hölderlin, éste no es sino uno de los rostros de la naturaleza, el más aparente pero no necesariamente el más verdadero. Para expresarlo en la terminología spinozista, Hölderlin considera la naturaleza sobre todo en su aspecto de natura naturans, aspecto al que subordina la natura naturata. La naturaleza se le presenta ante todo como infinita posibilidad, como indeterminación de la que brotan todas las determinaciones. El hombre que, paradójicamente, conquista su libertad oponiéndose en un primer momento a la naturaleza ${ }^{44}$, debe volver a ella para consumar esa libertad, entendida ya no como oposición al no-yo sino como identidad profunda entre el yo

42 Los hijos del limo (1993), p. 66.

43 Odas (1999), p. 129.

${ }^{44}$ Como afirma el poeta en su ensayo inacabado «Sobre la ley de la libertad», el autorreconocimiento de una conciencia como libre «presupone una resistencia de la naturaleza» (Ensayos (2001), p. 22). 
y el Todo. En la naturaleza, el ser humano no sólo descubre el mundo como «un acorde de seres libres» ${ }^{45}$. Asimismo, al reconocerse él mismo como divino ${ }^{46}$ siente que todo hombre es también parte de esa naturaleza divina y por tanto, su igual y su hermano.

Sin embargo, el sueño de Hiperión acabará desvaneciéndose. Las esperanzas puestas en una libertad política se dan de bruces con la violencia y la codicia de los seres humanos y el amor por Diótima revelará la necesaria asunción de los límites que implica una realidad humana finita. Y tener en cuenta la finitud humana supone no olvidar el límite inevitable de la muerte, que se llevará inesperadamente a su joven amada. No obstante, si bien la asunción de los límites supone una experiencia dolorosa, preside la novela el propósito firme de conciliar la aspiración humana a lo absoluto con los límites que impone la misma condición humana: «¿La infinitud? ¿Y dónde está? ¿Quién la ha encontrado? El hombre quiere más que lo que puede. Esto al menos es verdad. Tú mismo lo has comprobado muy a menudo. También es necesario que así sea» ${ }^{47}$.

La concepción antropológica de Hölderlin se va configurando como una dialéctica entre lo finito y lo infinito, entre la necesidad del límite y la aspiración a lo ilimitado (un conflicto que representa, en el plano humano, la dialéctica entre la determinación y la indeterminación en el plano cósmico) tal como se muestra en una carta de 1796 en la que «el conflicto entre la aspiración a lo absoluto y la aspiración a la limitación» que caracteriza al hombre debe buscar para resolverse la guía del «ideal de la belleza» ${ }^{48}$. La belleza supone un ideal regulador que señala la posibilidad de resolución del conflicto en una armonía. La comprensión del mundo y la autocomprensión del ser humano pasan necesariamente por la experiencia estética. En este sentido, no es una cuestión en modo alguno secundaria el género literario en el que se escribe el Hiperión.

${ }^{45}$ Hiperión (1998), p. 189.

46 Así le dice Diótima a Hiperión: «Yo siento en mí una vida que no ha creado ningún dios ni engendrado mortal alguno. Creo que existimos por nosotros mismos, y que sólo nuestro libre impulso nos une tan íntimamente con el todo» (op. cit., p. 189). Nótese cómo, en las palabras de Diótima, se insinúa la ganancia de la nueva unión con la naturaleza tras haberse alejado de ésta: el espíritu humano se desgaja de la naturaleza al hacerse consciente pero, si su pertenencia original era algo dado, no elegido, ahora se trata de una decisión libre, querida.

47 Hiperión (1998), p. 65.

48 Correspondencia completa (1990), pp. 294-295. 
Una larga tradición filosófica ha venido acostumbrándonos a que los contenidos filosóficos se viertan, sobre todo, en géneros en prosa como son el tratado y el ensayo. Sin embargo, esto no ha sido siempre así. Basta acercarse a los presocráticos para descubrir la extraordinaria variedad de formas que puede adquirir el discurso filosófico ${ }^{49}$. Un ejemplo especialmente destacado lo tenemos en los diálogos platónicos, en los que la ficción dialogal sirve de cauce a una reflexión filosófica de gran altura. La admiración que Hölderlin muestra una y otra vez por Platón ${ }^{50}$ hace pensar que éste sea un modelo muy cercano. No obstante, conviene destacar una obviedad: Hölderlin no escribe en la época de los presocráticos sino en una época en la que, a pesar de algunos intentos de amalgamar literatura y filosofía, una y otra tienden a adscribirse a formas distintas. El hecho es que Hölderlin quiso escribir desde un género muy distinto al de la Crítica del juicio de Kant o a las Cartas sobre la educación estética del hombre de Schiller. Hölderlin no quiere limitarse a exponer una teoría sobre la belleza (como hace Schiller en sus Cartas, que pertenecen a un modo de escritura claramente distinto al de los poemas y las obras teatrales de éste). Quiere crear una obra bella que cumpla en sí misma, en su naturaleza estética, lo que defiende. Hay por tanto una toma de postura muy consciente en la adscripción genérica, que como demuestran las versiones previas, no fue una elección fácil, si bien todas las versiones conservadas nos muestran ya el intento de fusión, bien en prosa, bien en verso, entre poesía y filosofía.

Hölderlin sitúa explícitamente su Hiperión bajo dos etiquetas literarias: una de ellas será la de «novela». La otra será la referencia a su "carácter elegíaco», expresión sobre la que nos ocuparemos más tarde. Hiperión es, por su forma, una novela epistolar (género muy cultivado en el XVIII) y por su contenido, una novela filosófica. Aunque finalmente Hölderlin opta por la prosa (la versión métrica de 1795 se quedó en un esbozo), se trata asimismo de una novela a la que tanto por su lenguaje como por su fuerza simbólica podríamos calificar como novela poética. Así pues, en Hiperión, Hölderlin ensaya una fascinante combinación de pensamiento, narración y poesía.

49 Cf. A. Bernabé, «Introducción» a De Tales a Mileto... (2001), pp. 26-33.

${ }^{50}$ Como breve muestra, la rotunda afirmación que corona la introducción a una de las versiones previas del Hiperión: «Yo creo que al final exclamaremos todos: «iSanto Platón, perdona!, se ha pecado gravemente contra ti» (Hiperión. Versiones previas (1989), p. 149). 
Si uno de los temas centrales en Hölderlin es la relación entre lo finito y lo infinito, la forma narrativa habla por sí misma de la necesidad de que lo eterno se inscriba en lo temporal. Implícitamente parece como si todo el texto estuviera sostenido por la desconfianza ante toda verdad que no ha sido conquistada en el propio vivir. Hiperión, tras terminar de contarle a Belarmino una conversación con Diótima, constata que no puede transmitirle realmente lo que se dijeron, porque las palabras de Diótima sin Diótima son sólo letra muerta: «Esto fue lo que hablamos. Te doy el contenido, el espíritu de la conversación. Pero esto, ¿qué es sin la vida?» ${ }^{51}$. No basta con que conozcamos las ideas de Hiperión, sino saber cómo ha llegado a ellas y cómo se encarnan en su existencia concreta para, como lectores, poder encarnarlas asimismo en nuestra vida. De nuevo, encontramos aquí una reminiscencia platónica: la del mito de Theuth, dador de las letras a los hombres, tal como aparece en el Fedro, en el que el rey Thamus muestra su rechazo a la palabra escrita porque, con las letras, los hombres «llegarán al recuerdo desde fuera, a través de caracteres ajenos, no desde dentro, desde ellos mismos y por sí mismos» ${ }^{52}$. La aparente paradoja de la condena de la escritura en un texto escrito se resuelve por la convicción de Hölderlin de que la escritura poética es capaz de dar nueva vida a lo que, de otro modo, sería letra muerta. Pero esa exaltación del arte no se hace sino en detrimento de la filosofía: ésta, sin ayuda de la experiencia estética, no es sino un conjunto de abstracciones que no pueden encarnarse en realidad alguna. Desde este punto de vista, la forma narrativa permite el despliegue temporal de la verdad, de una verdad que, a pesar de su carácter intemporal, sólo puede conocerse, desde una perspectiva humana, en el tiempo. No cabe separar lo dicho por Hiperión y lo vivido por Hiperión. Sin el sujeto que enuncia, lo enunciado no es en rigor exactamente lo mismo. La reconciliación con la naturaleza del final de la novela (reconciliación no definitiva, pues, como en la escatología cristiana, existe también aquí una tensión entre el ya y el todavía no) sólo se ha hecho verdadera a través de la separación previa, de los sucesivos fracasos que han ido descartando formas falsas de reconciliación.

Entre esos fracasos, el más notable (y el que supondrá un giro notable de la acción) será el desengaño ante la acción revolucionaria. Un desengaño que tiene que ver más con los medios que con los fines: al igual que Hölderlin segui-

\footnotetext{
51 Hiperión (1990), p. 82.

52 Fedro (2008), p. 403.
} 
rá siendo un demócrata convencido después de la Revolución Francesa ${ }^{53}$, Hiperión no rechazará como falso su sueño de libertad y fraternidad humanas. El error está en el camino: el olvido de la finitud que lleva al hombre de acción a creer que encarna el Absoluto. Ni la violencia del Estado despótico ni la del nuevo Estado revolucionario pueden imponer por la fuerza un cambio moral en el hombre. No cabe sacralizar, por tanto la acción política y, aunque resulta especialmente condenable la tiranía del absolutismo monárquico, tampoco un gobierno revolucionario puede considerarse con derecho de encarnar el Todo:

Me parece que tú concedes demasiado poder al Estado. Éste no tiene derecho a exigir lo que no puede obtener por la fuerza. Y no se puede obtener por la fuerza lo que el amor y el espíritu dan [...] Siempre que el hombre ha querido hacer del Estado su cielo, lo ha convertido en su infierno ${ }^{54}$.

El tono casi libertario que encontramos en este texto nos recuerda a algunas de las afirmaciones más encendidas del más antiguo programa del idealismo alemán:

[...] quiero mostrar que no hay idea del Estado, porque el Estado es algo mecánico, como tampoco hay una idea de una máquina. Sólo lo que es objeto de la libertad se llama idea. ¡Tenemos, pues, que ir también más allá del Estado! - Pues todo Estado tiene que tratar a hombres libres como engranaje mecánico $[\ldots]^{55}$.

La visión política de Hölderlin puede considerarse insuficiente. Y de hecho lo es: sus advertencias tanto contra el Terror revolucionario como contra el absolutismo se quedan en el momento negativo de la crítica pero no pasan nunca a la propuesta. A pesar de su deseo de encarnar lo universal en la finitud, la única salida que se vislumbra para la comunidad política es la reconciliación con la naturaleza, pero para dicha reconciliación no se señala ninguna vía política, sino una búsqueda individual. No obstante, conviene no olvidar que Hölder-

53 Vid. A. Ferrer, Hölderlin (2004), pp. 163-169 y H. Cortés, Claves para una lectura de Hiperión (1996), pp. 135-196)

54 Hiperión (1990), p. 54.

55 F. Hölderlin, Ensayos (2001), pp. 29-30. 
lin no es un individualista: si de momento no se vislumbran salidas colectivas, cree que la razón de este desencanto radica en la época que le ha tocado vivir. El poeta no postula una huida del mundo, sólo un alejamiento temporal (aunque ese tiempo de espera hasta que vuelva a surgir una esperanza común pueda prolongarse, lamentablemente, más allá de la vida del propio Hölderlin). En el Hiperión, la reconciliación en el plano político se proyecta en un futuro sentido todavía como lejano. Aunque en buena medida su Hiperión son las Nuevas cartas sobre la educación estética del hombre que Hölderlin nunca llegó a escribir, lo cierto es que si comparamos el final de Hiperión con el final de las Cartas de Schiller, se perciben notables diferencias. En ambos textos encontramos una visión esperanzadora, pero la reconciliación de la nueva humanidad con la naturaleza que propone el eremita griego parece ser más consciente de sus dificultades que el ideal de un Estado estético propugnado por Schiller. La crisis de la Ilustración como programa moral y político es mucho más aguda en Hölderlin que en su maestro. Sin embargo, ello no significa que el poeta suabo opte por la pasividad o la renuncia a los ideales comunitarios por más que el subtítulo de la novela de Hölderlin (El eremita en Grecia) pueda orientar nuestra lectura en este sentido.

El aislamiento final de Hiperión de hecho no es total. No corta toda comunicación con los otros. Queda abierta una vía: las cartas que escribe a Belarmino y que constituyen la base de la novela. En este sentido, la elección del género de la novela epistolar no puede estar más justificado. Hiperión (como el propio Hölderlin) puede considerar lejana una verdadera comunidad de hombres libres, pero no ha renunciado a sentar las bases para que dicha comunidad sea posible. El diálogo epistolar entre Belarmino e Hiperión aúna tres dimensiones: el pasado (por el que las cartas constituyen también un diálogo del propio Hiperión consigo mismo, con el joven que fue), el presente (inevitable en toda conversación epistolar y que hace que el sueño de una comunidad verdaderamente humana no sea sólo un anhelo, sino algo que se cumple, aunque de forma muy limitada, en toda comunicación verdadera entre seres humanos) y el futuro (en el que se proyecta el ideal de una nueva humanidad reconciliada consigo misma y con la naturaleza). El eremita es aquí sobre todo un símbolo del artista en la sociedad. El poeta no pertenece del todo a su tiempo, porque no puede renunciar a la tensión entre la realidad y el ideal que nutre su capacidad creadora. Forma y no forma parte de la sociedad (recuérdese a este respecto la importancia que el extranjero y el viaje adquieren en la poesía 
de Hölderlin ${ }^{56}$ ): aunque su escritura supone siempre un tú, una comunidad de escucha, al mismo tiempo sabe que esa escucha plena sólo podrá darse en una comunidad verdaderamente fraterna. La dimensión política del Hiperión no puede limitarse a un desengaño frente a la acción revolucionaria: en la voz solitaria del eremita de Grecia, del poeta, se guarda la esperanza de una sociedad verdaderamente humana para un tiempo futuro. $Y$ esa sociedad futura no puede limitarse a ser el resultado de una reforma superficial: «!Que cambie todo a fondo! ¡Que de las raíces de la humanidad surja el nuevo mundo! ${ }^{57}$. El artista se convierte en el guardián de esa semilla de una realidad que maduró demasiado pronto. Hiperión, como el poeta que es Hölderlin, es así un educador del pueblo, aunque su labor educativa pueda pasar desapercibida. Y como muestra de esa educación estética, está el propio Hiperión. En términos de la teoría de los actos de habla de Austin, podríamos decir que la novela de Hölderlin es un texto performativo: hace lo que dice. Hölderlin no se limita a exponer sus ideas estéticas, éticas, políticas... Estas ideas toman cuerpo en la trama argumental de la novela, que se constituye en sí misma, como objeto estético, en experiencia estética y por tanto se trata de un texto que educa para la sensibilidad y desde la sensibilidad ${ }^{58}$. Pese al tono melancólico de buena parte del libro, hay una confianza en la capacidad transformadora del arte si bien se trata de una transformación que tarda en dar frutos visibles, por lo que fácilmente puede confundirse su lentitud con incapacidad. Hiperión, sin embargo, a través de su propia experiencia vital, ha aprendido a ser paciente. La naturaleza es no sólo el origen sino también la meta: su palabra no pierde nunca de vista ese destino, que constituye su esperanza.

No obstante, conviene no dejar de lado ese tono melancólico al que acabo de referirme. El optimismo con el que se cierra la novela no debería hacernos olvidar que la serenidad de Hiperión ha tenido que bregar con demasiados fracasos. El propio Hölderlin nos habla, en los inicios de la novela, de su «tono

56 Un aspecto que ha destacado repetidas veces Heidegger: «La historicidad de la historia tiene su esencia en el retorno a lo propio, y dicho retorno sólo puede llegar a ser bajo la forma de un viaje de salida a lo extraño» ("Memoria», Aclaraciones a la poesía de Hölderlin (2005), p. 105). También Adorno lo considera un elemento esencial, hasta el punto de que reprocha al autor de Ser y Tiempo su insistencia en que el extrañamiento supone sólo una forma de volver a lo propio («Parataxis. Sobre la poesía tardía de Hölderlin» (2003), p. 438).

57 Hiperión (1990), p. 125.

58 Cf. A. Ferrer, Hölderlin (2004), pp. 85-89. 
elegíaco». Y Schiller había considerado precisamente la elegía como una modalidad muy significativa de la poesía sentimental ${ }^{59}$, es decir, de la que supone partir de una separación entre el yo poético y la naturaleza. Los momentos de comunión con la naturaleza existen para Hiperión como experiencia estética pero son momentos que no duran eternamente, epifanías que desaparecen para volvernos a dejar con la evidencia de la separación. Por ello, no es de extrañar que Hölderlin derive en su última etapa, la de sus más grandes poemas, antes de la caída en el vértigo de la locura, hacia modos de escritura que hacen de la experiencia de separación su propia sustancia. Me refiero fundamentalmente a la elegía y a la tragedia.

\section{Lo elegíaco y lo trágico. La lejanía de los dioses y el poeta en tiempos de miseria}

La redacción de Empédocles va acompañada, en Hölderlin, de un esfuerzo teórico por explicarse en qué consiste la tragedia, más allá de su forma superficial. A ello se suman, además, sus traducciones de Sófocles, tan denostadas en su tiempo y que, en la actualidad, han sido objeto de un renovado interés por parte de los estudiosos del poeta. Hölderlin concibe la tragedia desde una polaridad que trasciende lo puramente literario, la que se da, a su entender, entre lo orgánico y lo aórgico, entre lo determinado y lo indeterminado. Cada vez más el poeta es consciente de que la reconciliación con la naturaleza no es algo dado, sino fruto de un esfuerzo, un esfuerzo que necesita también de un momento de máxima separación (volvemos a la imagen de la órbita excéntrica) que puede entenderse también con un momento de lucha. El íntimo contacto con la cultura griega le permite a Hölderlin familiarizarse con el carácter agonístico (en el sentido etimológico de "lucha») que subyace a buena parte del pensamiento y la literatura helénicas. El conflicto, que revela la tragedia, sólo unilateralmente puede entenderse como opuesto a la reconciliación, porque sólo a través de dicho conflicto, exacerbado en la conciencia trágica, es posible alcanzar de nuevo la unidad anhelada. Sin embargo, al figurarse la separación bajo la imagen del conflicto, Hölderlin está acentuando la distancia entre el ser humano y el Uno divino, conflicto que no se produce sólo entre el hombre y lo sagrado sino también, en

\footnotetext{
59 Sobre Poesía ingenua y Poesía sentimental (1994), pp. 43-48.
} 
el seno de cada individuo, entre su tendencia a la individuación y su tendencia a ser uno con el Todo. Mediante esta lucha la naturaleza aórgica se hace más orgánica (más determinada gracias a la conciencia humana) y el ser humano se vuelve más aórgico. El héroe trágico acaba por saberse parte de la naturaleza que, anteriormente, se le presentó bajo la imagen de la hostilidad, de la alteridad absoluta frente a sí mismo. En ese conflicto entre el uno y lo Uno la razón no deja de desempeñar un papel importante, al mostrar la tensión existente entre lo orgánico y lo aórgico pero se trata de una tensión irresoluble en el plano estrictamente racional. Sólo proyectándose en la experiencia artística, y en concreto en la tragedia, la hostilidad se convierte en mutua pertenencia. Se trata de confrontar ambas fuerzas en la obra artística lograda, en la que los opuestos se unifican: cuando la diferenciación se hace más dolorosamente evidente se muestra asimismo «la más alta reconciliación» ${ }^{60}$.

La aspiración del ser humano hacia el Uno debe hacerse cargo de una experiencia que no puede ser sino conflictiva: porque el ser humano quiere al mismo tiempo ser más su propio yo, ser uno consigo mismo superando toda escisión y a la vez quiere ser Uno con la naturaleza. Pero al querer ser más universal, lo particular se halla en peligro. En ese peligro Hölderlin cree encontrar una vía paradójica de salvación (como dirá en su hermoso poema "Patmos», «Pero donde hay peligro, / crece lo que nos salva ${ }^{61}$ ). Sin embargo, dicha salvación sólo puede darse en la más alta conciencia del peligro, en la exacerbación del peligro hasta lo intolerable como se percibe, por ejemplo, en la figura de Antígona ${ }^{62}$.

Si la novela había servido, en el Hiperión, como expresión de cómo lo infinito debe encarnarse en lo finito y cómo lo intemporal necesita desplegarse en lo temporal, la forma teatral del Empédocles muestra, en el diálogo, la necesidad de buscar la unidad mediante la contraposición de los principios que encarnaran los diferentes personajes. Por otra parte, la elección de la figura de Empédocles no es casual. Sin duda, le interesa al poeta una figura en la que la filosofía encuentra cauces poéticos de expresión y al que no son ajenas las preocupaciones religiosas y políticas. Es probable que no le dejara indiferente una filosofía en la cual el cosmos aparece animado por dos fuerzas opuestas, el Amor y el Odio

\footnotetext{
60 "Fundamento para el Empédocles», Ensayos (2001), pp. 116-117.

61 Vid. F. Hölderlin, Antología poética (2002), p. 213.

62 "Notas sobre «Antigona», Ensayos, ed. cit., pp. 162-163.
} 
(y si Hölderlin insiste en el Amor entendido en clave neoplatónica como lazo de unión del cosmos, cada vez es más consciente de que el momento de separación es esencial en la dinámica de la naturaleza). Pero, ante todo, más que su pensamiento, lo que fascina a Hölderlin es la leyenda de la muerte del filósofo de Agrigento, como la había leído en las Vidas de filósofos ilustres. De la versión de Diógenes Laercio, Hölderlin toma sólo lo que le interesa: la autoinmolación de Empédocles que, para Hölderlin, representa la reintegración en el Todo. De la desmitificación de su muerte, que atribuye su suicidio a un simple acto de vanidad superficial, apenas quedan rastros en la obra, aunque probablemente esa perspectiva haya servido a Hölderlin para intentar comprender el punto de vista de los antagonistas de su personaje principal.

Resulta muy tentador interpretar la historia de Empédocles en clave mítica, y no en cualquier clave mítica sino en la de un mito prometeico ${ }^{63}$ : desde este punto de vista, Empédocles, al arrojarse al Etna, estaría desafiando los límites que los dioses han impuesto a los mortales. Sin embargo, uno de los rasgos más notables de la lectura que hace Hölderlin en su Empédocles es que el poeta se esfuerza en no convertir la leyenda de la muerte del filósofo en una versión de Prometeo. Ello resulta especialmente notable porque los mitos prometeicos eran especialmente caros tanto a la Ilustración como al Romanticismo. La obra de Hölderlin le debe no poco a la reflexión filosófica y artística de la Ilustración, pero Hölderlin no es un ilustrado. En ocasiones la escritura del gran poeta alemán recuerda al Romanticismo, que empieza a nacer en estos momentos. Con todo, tampoco puede decirse que Hölderlin sea un autor estrictamente romántico. Esa singularidad de su voz poética se muestra aquí también, en su rechazo a los mitos prometeicos. Este distanciamiento le lleva a no querer convertir a Empédocles en el hombre-dios, que sería la máxima hybris para el mortal. En la primera versión del Empédocles, uno de los enemigos del héroe, Hermócrates, señala el delito de Empédocles: proclamarse «un dios ante todo el pueblo» ${ }^{64}$. Empédocles ha reconocido en sí mismo la divinidad que hay en Todo. Al sentirse uno con la naturaleza, no puede dejar de reconocerse en cierto modo divino, y por ello fustiga con justicia a Hermócrates, representante de una religión sacerdotal y dogmática. Quien reconoce lo divino en sí mismo (como quería, por otra parte, el llamado «El más antiguo programa de sistema del idealismo

${ }^{63}$ Cf. A. Ferrer, Hölderlin (2004), pp. 128-130.

${ }^{64}$ Empédocles (1997), p. 53. 
alemán ${ }^{65}$ ) evita ciertamente la hybris del sacerdote que confunde, consciente o inconscientemente, el poder establecido del que él mismo forma parte con la voluntad divina. Sin embargo, tiene que protegerse de otro tipo de hybris: la de hacer de sí mismo un dios.

Como ha señalado Michael Knaupp, uno de los principales problemas de Hölderlin a la hora de dar una versión definitiva a su poema dramático fue precisamente su duda ante cómo encarar la cuestión de la hybris ${ }^{66}$. De hecho, la dificultad para dar un tratamiento adecuado a esta cuestión es la que, al parecer, motiva que el texto quede inacabado. La decisión de arrojarse al Etna no puede confundirse, para Hölderlin, con el acto prometeico de robar el fuego de los dioses. Si la tragedia revela un antagonismo entre los hombres y los dioses, dicho antagonismo sólo puede resolverse en una doble asunción de los límites humanos y de la pertenencia al Uno, a la naturaleza. En cada nueva versión del Empédocles, Hölderlin se ve cada vez más en aprietos para justificar el suicidio de su héroe hasta que finalmente (en un acto de honradez artística e intelectual que le honra) deja el proyecto inacabado. En Hölderlin parece ir surgiendo la sospecha de que tal vez el acto de inmolación del héroe resulta difícilmente justificable: ¿cómo podrá borrar el acto de orgullo de haberse acercado demasiado a los dioses un suicidio que pretende precisamente unirse con lo divino? Hölderlin empieza a sospechar que la pretensión de su héroe constituye en el fondo la hybris máxima. Y no se trata de una mera cuestión literaria: Hölderlin ve poner en peligro su propia aspiración a lo absoluto, que se le presenta como un anhelo desmesurado. Hölderlin encuentra de pronto en su propia obra un espejo inquietante: ¿la fusión con el Todo no supone la muerte entendida no ya como reconciliación, sino como simple aniquilación de lo individual? Ya en Hiperión, Diótima tiene que morir. La persona concreta, la mujer de carne y hueso, debe desaparecer para dejar paso al Amor cósmico. En la novela es la propia Diótima la que acepta este destino. Sin embargo, ni el recurso a la necesidad interna del texto novelístico ni la exaltación del Amor como ley de la naturaleza llegan a disipar

65 «Finalmente vienen las ideas de un mundo moral, divinidad, inmortalidad — subvertir toda falsa creencia-, perseguir al clero, que últimamente finge Razón, mediante la Razón misma. Absoluta libertad de todos los espíritus, que portan en sí el mundo intelectual y que no deben buscar fuera de sí ni Dios ni inmortalidad» (Ensayos (2001), p. 30).

66 "Prólogo (a la edición española del Empédocles)», pp. 15-21, en F. Hölderlin, Empédocles (1997). Cf. S. Mas, Hölderlin y los griegos (1999), pp. 151-155. 
la inquietud de que tal vez no sea tan fácilmente conciliable el amor entendido como afecto hacia un ser finito, concreto, y el Amor como ley cósmica que rebasa lo individual. Hölderlin, al matar a Diótima, lejos de solucionar la tensión entre la tendencia a la individuación y la tendencia hacia lo Absoluto, nos muestra la dificultad de una solución definitiva. De igual manera, la muerte de Empédocles nos sitúa ante la posibilidad de que lo que hasta ahora se había planteado como reconciliación de los opuestos no sea sino una falsa conciliación, basada precisamente en la supresión de uno de los dos principios en conflicto.

A ello se une otra cuestión, que probablemente también contribuyó a que Hölderlin fuera incapaz de rematar su proyecto y que, sólo en apariencia, nada tiene que ver con el tema de la desmesura. En su ensayo sobre «Los géneros poéticos», Hölderlin considera que en el poema trágico debe tener menos peso el «elemento terrestre» ${ }^{67}$ que en el poema épico y el poema lírico. En coherencia con su propia poética, el conflicto del Empédocles se va haciendo cada vez más abstracto, hasta el punto de que las individualidades de los distintos personajes se diluyen en un conflicto de fuerzas universales (algo que, en un género teatral como es la tragedia, supone para la obra una herida de muerte, porque si algo le es esencial al género dramático es que los personajes sean algo más que el vehículo de ideas o principios). Sin embargo, en Hölderlin rara vez un problema literario es sólo un problema literario. La progresiva abstracción del conflicto lleva precisamente a olvidar la pretensión de Hölderlin de unificar, mediante el arte, lo individual y lo universal. A estas alturas Hölderlin sabe perfectamente que no se puede lograr dicha reconciliación ignorando el problema: desdibujar el yo de los personajes no supone la conquista de la universalidad, sino una falsa absorción de lo particular en un universal abstracto (en una abstracción que es la que precisamente Hölderlin recrimina a la filosofía y que dificulta una verdadera experiencia estética). Cuando abandona el proyecto, Hölderlin sabe ya que ha llegado demasiado lejos ${ }^{68}$.

No obstante, el planteamiento político que efectivamente va pasando a segundo plano, no deja de tener interés. Cuando el Empédocles de Hölderlin rechaza

${ }^{67}$ Ensayos (2001), p. 91.

${ }^{68}$ Cf. Michael Knupp, «Prólogo (a la edición española del Empédocles)» (1997), pp. 20-21. Como dice Salvador Mas, Hölderlin tiene finalmente que preguntarse si Hermócrates no tendrá en el fondo razón en sus críticas a Empédocles (Hölderlin y los griegos (1999), p. 48). 
convertirse en monarca, porque "ya no es tiempo de reyes» ${ }^{69}$, no está simplemente resaltando su falta de ambición en el terreno político. Aquí no sólo Hölderlin recoge un aspecto importante del Empédocles histórico, su decidida defensa de la democracia ${ }^{70}$, sino que al mismo tiempo se sitúa conscientemente en una lectura de Grecia (y de su momento presente) muy alejada de una comprensión política autoritaria. La negativa de Empédocles a convertirse en rey nos sitúa ante una posición muy distinta a la del Rey-Filósofo platónico. Empédocles ilumina, por su experiencia de lo divino, a su pueblo y, sin embargo, se resiste a convertir esa experiencia en poder. La actitud de Empédocles frente al pueblo recuerda mucho a lo que afirma Jaeger de Heráclito, de quien quizás no en vano en la Antigüedad se hizo con frecuencia una lectura ético-política antes que ontológica: para Jaeger, el filósofo de Éfeso revela que la función social del filósofo, pese a su aislamiento, es mostrar un logos común a la comunidad ${ }^{71}$. De ahí la peculiar posición del filósofo: está, a la vez, dentro y fuera de la polis, como el poeta, como el eremita Hiperión, como el mismo Hölderlin. Lo que afirma Jaeger de Heráclito (otro de los genios tutelares del poeta alemán) bien puede aplicarse a Hölderlin si sustituimos la figura del filósofo por la del poeta y el logos puramente racional por un Arte con mayúsculas que pretende reconciliar lo particular y lo universal en la experiencia estética. Sin embargo, esa unidad que reconcilia lo diverso a través del arte puede ser una morada, un espacio, pero no puede transformarse en un poder directivo que sustituya la libre discusión de una comunidad de hombres libres. El desencanto político de Hölderlin no supone una concesión al absolutismo, sino la exigencia de no ceder demasiado pronto a la convicción de que se han cumplido todas las aspiraciones de igualdad y libertad entre los seres humanos.

La postura democrática del poeta no ha cambiado: la solución no está ni en reyes-filósofos ni en poetas-reyes. El poeta puede advertir a los hombres sobre su desmesura, sobre su pretensión de agotar lo absoluto en realidades que son históricas y como tales contingentes: ni el Estado ni el dogma religioso ni la acción política son absolutos que justifiquen el sometimiento o la destrucción de todo aquello que no puedan integrar dentro de sí. El poeta puede ser en todo caso el

${ }^{69}$ Empédocles (1997), p. 163.

70 Cf. A. Bernabé, De Tales a Demócrito... (2001) pp. 181-182 y Diógenes Laercio, op. cit. (2007), pp. 442-443.

${ }^{71}$ W. Jaeger, La teología de los primeros filósofos griegos (2003), pp. 116-117. 
anunciador de una nueva comunidad humana, pero es la propia comunidad la que debe darse sus propias normas. El Empédocles de Hölderlin no puede mostrarse más radical al respecto: «Avergonzaos / por querer aún un rey» ${ }^{72}$. Quizá por ello la educación estética que propone Hölderlin no nos resulte tan incómoda como algunos de sus modelos contemporáneos. Las dudas del propio Hölderlin sobre el valor de la poesía así como sus convicciones democráticas le hace alejarse de un peligro al que parecía abocada su visión del arte. A pesar de que en ocasiones su pensamiento se acerca peligrosamente a ello, finalmente Hölderlin aleja de sí mismo, probablemente no sin escaso sufrimiento personal, la tentación de una esteticización de la política ${ }^{73}$. Quizá sea esa una de las razones por las que Hölderlin siga siendo nuestro contemporáneo, porque su propia lucidez le lleva a no confundir en una monstruosa unidad estética y política (lo que no quiere decir, por supuesto, que el arte excluya contenidos políticos ni que la política pueda prescindir de las preguntas que dejan en el aire las grandes obras de arte). Ni mitología de la razón en el sentido del primer programa del idealismo alemán ni Estado estético en la perspectiva más pendiente de Schiller, el pensamiento trágico ${ }^{74}$ de Hölderlin le lleva a mantener una distante prudencia entre la búsqueda personal del artista y la búsqueda colectiva que supone la acción política. Si la función del arte se limita a dotar de fuerza irracional y mítica a los principios supuestamente racionales de una ideología política, si el arte se limita a prestar su capacidad de persuasión retórica a quienes pretenden mantenerse en el poder o conquistarlo, ¿no se convierte el arte en un simple arte sofístico, en una forma invisible pero quizás más insidiosa de violencia? La distancia entre la unidad lograda en la obra de arte y la unidad nunca definitiva de la comunidad política pude resultar dolorosa pero es la que le permite al arte mantener su capacidad crítica y a la política su capacidad de interrogarse a sí misma.

La dolorosa distancia entre la unidad conseguida en la obra de arte y la realidad fragmentaria subyace a buena parte de la poesía madura del Hölderlin, sobre todo a las grandes elegías, probablemente el culmen de su producción poética. Puede parecer contradictorio que, precisamente en sus poemas más logra-

${ }^{72}$ Op. cit., p. 165.

73 Resulta interesante al respecto la lectura del libro de Philippe Lacoue-Labarthe Heidegger. La política del poema (2007).

${ }^{74}$ Sobre el pensamiento trágico en Hölderlin, resulta imprescindible el libro de Rafael Argullol (El Héroe y el Único (2008), pp. 57-121). 
dos, la armonía entre los distintos elementos que configuran la unidad de la obra no se consiga sino a través de una tensión, de esas «yuxtaposiciones ásperas» a las que se refería Hellingrath ${ }^{75}$ y que Adorno, en un estudio imprescindible, ha estudiado como una tendencia hacia las estructuras paratácticas ${ }^{76}$. Si en el nivel sintáctico los enunciados parecen acumularse como fragmentos de un discurso cuya ilación resulta en ocasiones problemática, el efecto estético es el de una unidad profunda, la de un texto de una intensidad poética pocas veces alcanzada en la historia de la lírica. Pero lo fragmentario late ahí como una amenaza que no deberíamos ignorar. Los momentos de plenitud y serenidad que logran estos poemas tienen poco que ver con la serenidad del clasicismo dieciochesco. Como en su concepción de la tragedia, también en sus elegías pugnan y llegan a confundirse la máxima reconciliación con la máxima hostilidad.

Sin duda, uno de los grandes temas que dota de unidad al conjunto de las elegías es la presencia de lo divino. Sin embargo, se trata de una presencia fugaz, que apenas puede apresar el presente y que se proyecta bien hacia la nostalgia de un pasado, bien hacia la esperanza futura de dioses venideros. Como escribe Gadamer, «Lo que construye en su obra poética ya no es una nueva concepción religiosa, legitimada por una revelación divina, sino la interpretación del ente y del mundo desde la certeza del alejamiento de los dioses» ${ }^{77}$. Aunque el lamento por la lejanía de los dioses proviene de una voz individual, no deja de tener una dimensión colectiva. El momento presente parece haber alejado a los dioses y, como en el bellísimo poema "El Archipiélago», el retorno de los dioses se confunde con el retorno de una Grecia utópica revivida. La nostalgia por los dioses perdidos es al mismo tiempo la nostalgia de una auténtica comunidad (la única quizás capaz de crear nuevos dioses) ${ }^{78}$. Asimismo, en su ensayo inacabado «Sobre la religión», Hölderlin plantea la necesidad de encontrar lo divino dentro de nosotros mismos pero el nacimiento de los dioses sólo puede darse en la mutua

75 Vid. Gadamer, «Hölderlin y George» (1999), p. 37.

76 «Parataxis. Sobre la poesía tardía de Hölderlin» (2003). Escribe asimismo Jenaro Talens sobre las elegías: «[...] la disgregación y la tendencia al fragmentarismo ya están presentes en estos largos poemas en los que las digresiones y las repeticiones luchan por hacer estallar una aparente serenidad y una estructura tan sólida en su superficie como llena de grietas, al pretender construir un mundo que su lúcida locura posterior asumiría como imposible» («Nota a esta edición»en F. Hölderlin, Las grandes elegías (1998), p. 19.

77 Art. cit., p. 42.

${ }^{78}$ Las grandes elegias (1998), pp. 21-45. 
relación humana ${ }^{79}$. Quien está lejos de su patria verdadera (que, para Hölderlin, en este momento, es la patria de una verdadera comunidad de hombres libres) está también lejos de sus dioses. Más adelante en el mismo ensayo, defenderá que las relaciones religiosas son míticas $y$, por tanto, poéticas ${ }^{80}$.

Los dioses, en la concepción de Hölderlin, parecen ser figuras, concreciones temporales de lo sagrado indisponible, de ese fondo último de lo real que constituye la naturaleza como divinidad inmanente ${ }^{81}$. Se convierten así en figuras intermediarias entre los hombres y el Todo. El problema es que Hölderlin sabe que la suya es una época que desconfía de las mitologías, un tiempo en el que el mito y la razón se consideran enemigos irreconciliables. Y el intento de conciliar mito y razón a través de la poesía no deja de resultar problemático. Los dioses efectivamente son reales dentro del mundo creado por el poema ${ }^{82}$. Cuando se produce una auténtica experiencia estética, la realidad del poema se nos impone como una verdad propia. Sin embargo, cuando volvemos a la experiencia cotidiana, dicha certeza desaparece. Hölderlin intenta salvar la experiencia religiosa, cuestionada seriamente por la Ilustración, desprendiéndola de dogmatismos y asimilándola a la experiencia estética. Se trata de una experiencia incuestionable por sí misma, pero, como tal experiencia, es puramente individual y su pretensión de universalidad sólo puede justificarse vagamente en una cierta analogía con otras experiencias individuales, pero sin que haya una certeza que provenga de otro ámbito que el de la misma vivencia artística. Mientras la vivencia mítica no es cuestionada, la propia experiencia basta. Sin embargo, basta que empiece a cuestionarse para que tengamos que buscar su fundamentación en otro ámbito distinto a sí misma. El problema es que no podemos pedir ayuda ahora a la razón. Al negar a la razón capacidad para intuir la verdadera realidad (al tirar la

79 Ensayos (2001), pp. 100-101.

${ }^{80}$ Op. cit., p. 103.

81 «La naturaleza es anterior a todo lo real y a todo obrar, también anterior a los dioses [...] Lo sagrado no es sagrado por ser divino, sino que lo divino es divino por ser «sagrado" a su manera» (M. Heidegger, "Como cuando en día de fiesta", Aclaraciones a la poesía de Hölderlin (2005), p. 66). Una concepción semejante sobre lo sagrado como fondo indisponible y lo divino como figura de lo sagrado la encontramos en María Zambrano (El hombre y lo divino (2005), pp. 27-43).

${ }^{82}$ Como afirma Schelling, "Todas las figuras del arte, por tanto, preferiblemente los dioses, son reales porque son posibles» (Filosofía del arte (1999), p. 49). Sobre lo real y lo irreal, véase la reflexión de Heidegger a propósito de Hölderlin («Memoria», Aclaraciones a la poesía de Hölderlin (2005), pp. 124-129). 
escalera, como decíamos en el primer apartado de este trabajo) no podemos pretender volver a recuperarla.

La experiencia poética de lo divino muestra, a la postre, una problemática similar a la que plantea la experiencia mística: mientras se presenten como experiencias puramente individuales y no busquen una fundamentación fuera de sí mismas, son incuestionables. El problema viene cuando se busca explicar la realidad de dichas experiencias desde otros campos. Para decirlo con Wittgenstein, una experiencia mítica como la que plantea Hölderlin es válida dentro de su propio juego de lenguaje, pero resulta difícil su traducción a otros juegos. ¿Son traducibles, por ejemplo, las imágenes míticas de la naturaleza al lenguaje de las ciencias naturales, que están alcanzando un desarrollo tan importante en los siglos XVIII y XIX? Mientras la imagen de una Grecia utópica como la que aparece en Hölderlin sea una creación autónoma del espíritu no hay ningún problema, pero si pretende ser algo más que eso, ¿̇cómo no va a entrar en conflicto con la investigación historiográfica sobre la Grecia real, que distaba mucho de ser una sociedad armónica? ${ }^{83}$. Al pretender salvar con un salto (mítico, poético) la distancia entre la razón y la intuición, Hölderlin nos sitúa sin pretenderlo ante la precaria certeza de lo divino en un mundo que carece de dioses compartidos (tal vez porque, como se dice en una de las versiones previas de Hiperión, los hombres han matado al dios de la edad presente ${ }^{84}$ ). El gran arte nos permite acceder a momentos de epifanía, en los que creemos presentir una unidad más allá de nuestras limitaciones, un instante cargado de sentido. Sin embargo la epifanía, por su propia realidad, es siempre fugaz. Y cuando desaparece, queda un recuerdo que no puede sustituir a la presencia: «el hombre soporta la plenitud divina sólo un tiempo. / Después soñar con ellos es toda nuestra vida ${ }^{85}$. La poesía no deja de afrontar con lucidez esa ausencia de lo sagrado pero al mismo tiempo nos revela la nostalgia de esos dioses en los que cada vez nos resulta más difícil creer. Una nostalgia que a veces se convierte en espera activa, como en los versos de Hölderlin del mismo poema:

83 Cf. S. Mas, Hölderlin y los griegos (1999), pp. 69-158.

84 «La fábula habla de hombres, ella habría matado a la actual divinidad» (Hiperión. Versiones previas (1989), p. 162. Anacleto Ferrer, ante esta enigmática frase de un texto, por otra parte, muy fragmentario, señala: «Esta podría ser, dentro de su ambigüedad, la primera formulación del concepto «muerte de Dios» (op. cit., p. 168).

85 «Pan y vino», Las grandes elegías (1998) p. 115. 


\section{[...] y, ¿para qué poetas en tiempos de miseria?}

Pero, me dices, son como los santos sacerdotes del dios de los viñedos que de una tierra vagan a otra tierra en la noche sagrada ${ }^{86}$.

El intento de salvar la experiencia de lo divino a través de la poesía no sólo nos conduce a constatar la ausencia de los dioses sino también termina cuestionando la validez de la propia poesía. Sin embargo, el propio Hölderlin se apresura a contestar la inquietante pregunta. El poeta aparece como guardián de lo sagrado, de la aspiración a lo Absoluto. Su figura es así similar a la de un sacerdote, pero un sacerdote de Dionisos, el «dios de los viñedos», es decir, no un sacerdote que se identifique con un dogma o con una estructura de poder, sino con la experiencia dionisiaca de lo que nos desborda. Son sacerdotes sin territorio fijo ("de una tierra vagan a otra tierra»), por tanto, son siempre forasteros donde quiera que vayan. De nuevo, el poeta, en relación con los demás seres humanos, aparece no como un caudillo político o religioso, sino como un extranjero que viene de lejos y repite las preguntas que la mayoría ha olvidado. La relación de la poesía con lo sagrado se convierte así en una relación incómoda, en la que la esperanza convive con el desasosiego. Escribe Heidegger:

[...] es justamente en la medida en que Hölderlin funda de nuevo la esencia de la poesía por lo que podemos decir que determina un nuevo tiempo. Es el tiempo de los dioses huidos y del dios venidero. Es el tiempo de penuria, porque se encuentra en una doble carencia y negación: en el ya-no de los dioses huidos y en el todavía-no del dios venidero ${ }^{87}$.

Pero tal vez en esa doble ausencia de la que habla Heidegger pueda haber un elemento de afirmación, no puramente negativo. En la ausencia del dios, lo divino no puede convertirse en sujeto del poder. El recuerdo de esa presencia de los dioses supone una seria advertencia para el mortal, que no se ve legitimado para ocupar el lugar de los dioses, que no puede él mismo convertirse en hombre-dios. Como afirma Empédocles en la tragedia de Hölderlin, que «lo divino no se convierta en obra humana ${ }^{88}$. En la elegía «Stuttgart», la nostalgia del poeta sirve asimismo de advertencia contra cualquier tentación de encarnar el absoluto en la

${ }^{86}$ Id., p. 115.

87 "Hölderlin y la esencia de la poesía», Aclaraciones a la poesía de Hölderlin (2005), p. 52.

${ }^{88}$ Empédocles (1997), p. 187. 
finitud. El poeta se lamenta porque «faltan nombres sagrados» ${ }^{89} \mathrm{y}$, sin embargo, acepta que ante lo sagrado no cabe con frecuencia otra actitud que el silencio. Es preferible callar antes que pretender falsamente hablar en nombre de lo sagrado. Teología y filología se confunden en "Stuttgart» en la pregunta sobre qué realidad hay detrás del discurso sobre los dioses. ¿Es la poesía sólo lenguaje o, a través de ella, se convoca una realidad no reducible a discurso lingüístico? El poeta ha buscado en el arte una inmediatez, un contacto directo con lo Real con mayúsculas. Pero Hölderlin no ignora que el lenguaje es siempre mediación, que el nombre no es la cosa sino un intermediario entre el que nombra y lo nombrado. Escribe lúcidamente Paul de Man:

No porque haya visto al Ser, es el poeta capaz de nombrarlo; su palabra ruega y pide la parusía pero no la establece.

No puede establecerla porque la palabra al pronunciarse destruye lo inmediato y descubre que, en vez de expresar el Ser, sólo puede expresar la mediación ${ }^{90}$.

$\mathrm{Al}$ poeta sólo le cabe esperar, pero esa espera supone mantener un espacio abierto entre el hombre y lo divino. Así, aunque esta ausencia de los dioses parece una versión débil de la muerte de Dios, que no se contenta con una ausencia definitiva, lo fundamental es que, vengan o no los dioses que espera anhelante el cantor elegíaco, el poeta lanza una seria advertencia a cualquiera que quiera ocupar el puesto vacante. Es mejor soportar la angustia ante un cielo vacío que buscar sucedáneos a la experiencia radical de lo sagrado. Como señala Heidegger, el poeta

Es alguien que ha sido arrojado fuera, y afuera quiere decir a ese Entre que se halla entre los dioses y los hombres. Pero ese espacio intermedio es precisamente el único y el primer lugar donde se decide quién es el hombre y dónde establece su existir ${ }^{91}$.

${ }^{89}$ Las grandes elegías (1998), p. 93.

90 «Heidegger y las exégesis de Hölderlin» (1991), p. 294. Adorno destaca también esta distancia entre el nombre y lo nombrado («Parataxis...» (2003), p. 445).

91 «Hölderlin y la esencia de la poesía», Aclaraciones a la poesía de Hölderlin, (2005), p. 51. 
La condición humana se muestra, en la poesía de Hölderlin, como una condición fronteriza, como la de alguien que pertenece a la tierra y no pertenece del todo a ésta. Por ello busca en lo terrenal signos de conciliación entre la finitud y lo celestial, como son el pan y el vino en la elegía del mismo nombre Volvamos a una de las cimas de la poesía de Hölderlin:

El pan es el fruto de la tierra y sin embargo lo bendice la luz y del tronante dios nos llega la alegría del vino.

Por eso nos recuerdan los celestiales que en otro tiempo nos acompañaron y han de volver un día, por eso los poetas cantan al dios del vino con solemnidad y no resuena fútil su alabanza para el antiguo dios ${ }^{92}$.

La espera de Hölderlin no deja entrever tan sólo la ausencia. No impone un silencio definitivo ni se proyecta únicamente hacia el futuro. Lo terrestre, el vino y el pan (que reconcilian aquí su significado cristiano y su significado pagano), son, en estos versos, presencia de lo divino, de una naturaleza que no se deja reducir a la comprensión humana. La locura de Dionisos como la locura poética de Apolo ofrecen al mortal la posibilidad de soñar lo eterno en el seno de la temporalidad. El esfuerzo de Hölderlin en sus elegías por reconciliarse con la finitud no le permite otorgarnos ninguna certeza de reconciliación definitiva con el Todo, pero sí es recompensado con la belleza de una obra que, sin ser reconocida por sus contemporáneos, se ha convertido en nuestra contemporánea. Y sí Hölderlin sigue siendo uno de nuestros poetas más vivos quizá lo sea porque, aun a su pesar, su obra no oculta las tensiones y contradicciones que le dan vida.

\section{Bibliografía}

\section{Obras de Friedrich Hölderlin}

(1989). Hiperión. Versiones previas (traducción de Anacleto Ferrer). Madrid: Hiperión, (1990). Correspondencia completa (traducción de Helena Cortés y Arturo Leyte). Madrid: Hiperión.

(1997). Empédocles (traducción de Anacleto Ferrer). Madrid: Hiperión.

(1998). Las grandes elegias (1800-1801) (traducción de Jenaro Talens). Madrid: Hiperión.

${ }^{92}$ Las grandes elegías (1998), p. 117. 
(1998). Hiperión o El eremita de en Grecia (traducción de Jesús Munarriz). Madrid: Hiperión. (1999). Odas (traducción de Txaro Santoro). Madrid: Hiperión.

(2001). Ensayos (traducción de Felipe Martínez Marzoa). Madrid: Hiperión.

(2002). Antología poética (traducción de Federico Bermúdez-Cañete). Madrid: Cátedra.

(2005). Los himnos de Tubinga (traducción de Carlos Durán y Daniel Innerarity). Madrid: Hiperión.

\section{Sobre Hölderlin}

Adorno, Th. W. (2003). «Parataxis. Sobre la poesía tardía de Hölderlin» en Notas sobre literatura. Obra completa, 11 (traducción de Alfonso Brotons Muñoz). Madrid: Akal.

Argullol, Rafael (2008). El Héroe y el Único. El espíritu trágico del Romanticismo. Barcelona: Acantilado.

Cortés Gabaudan, Helena (1996). Claves para una lectura de Hiperión. Filosofía, politica, ética y estética en Hölderlin. Madrid: Hiperión.

De Man, Paul (1991). «Heidegger y las exégesis de Hölderlin», Visión y Ceguera: Ensayos sobre la retórica de la critica contemporánea (traducción de Hugo Rodríguez-Vecchini y Jacques Lezra). Rio Piedras, Universidad de Puerto Rico.

FERrer, Anacleto (2004). Hölderlin. Madrid: Síntesis.

Gadamer, Hans-Georg (1999). Poema y diálogo (traducción de Daniel Najmías y Juan Navarro). Barcelona: Gedisa.

HeIDEgGer, Martin (2005). Aclaraciones a la poesía de Hölderlin (traducción de Helena Cortés y Arturo Leyte). Madrid: Alianza.

Martínez Marzoa, Felipe (1995). Hölderlin y la lógica hegeliana. Madrid: Visor.

MAS, Salvador (1999). Hölderlin y los griegos. Madrid: Visor.

\section{Otras}

BernabÉ, Alberto, ed. (2001). De Tales a Demócrito. Fragmentos presocráticos. Madrid: Alianza.

Diógenes Laercio (2007). Vidas de los filósofos ilustres (traducción de Carlos García Gual). Madrid: Alianza.

Hegel, G. W. F. (1985). Estética. La Poesía (traducción de Alfredo Llanos). Buenos Aires: Siglo XX. 
Lacoue-Labarthe, Philippe (2007). Heidegger. La politica del poema (traducción de José Francisco Megías Flórez). Madrid: Trotta.

JAEGER, Werner (1977). La teología de los primeros filósofos griegos (traducción de José Gaos). Madrid: FCE.

KanT, Emmanuel (1984). Crítica del juicio (traducción de Manuel García Morente). Madrid: Espasa-Calpe.

KLEIST, Heinrich von (1988). Sobre el teatro de marionetas y otros ensayos de arte y filosofia (traducción de Jorge Riechmann). Madrid: Hiperión.

PAZ, Octavio (1993). Los hijos del limo. Del romanticismo a la vanguardia. Barcelona: Seix Barral.

Platón (1992). La república (traducción de José Manuel Pabón y Manuel FernándezGaliano). Madrid: Alianza.

Platón (2008). Diálogos III. Fedón, Banquete, Fedro (traducción de Carlos García Gual, M. Martínez Hernández y Emilio Lledó). Madrid: Credos.

Rivera De Rosales, J. (1996). «El primer principio en Fichte» en Oswaldo Market y Jacinto Rivera de Rosales (Coordinadores), El inicio del idealismo alemán. Madrid: Editorial Complutense/ UNED, pp. 63-102.

Rousseau, J. J. (1970). Discurso sobre el origen y los fundamentos de la desigualdad entre los hombres (traducción de Melitón Bustamante Ortiz). Barcelona: Península.

SCHELLING, Friedrich Wilhelm Joseph von (1999). Filosofía del arte (traducción de Virginia López Domínguez). Madrid: Tecnos.

SCHILLER, Friedrich (1990). Kallias. Cartas sobre la educación estética del hombre (traducción de Jaime Feijóo). Barcelona. Anthropos.

SCHILler, F. (1994). Sobre Poesía ingenua y Poesía sentimental (traducción de Juan Probst y Raimundo Lida). Madrid. Verbum.

SCHLEGEL, Friedrich (2005). Conversación sobre la poesia (traducción de Laura S. Carugati y Sandra Girón). Buenos Aires. Biblos.

SPINOZA, Baruch (2006). Ética demostrada según el orden geométrico (traducción de Vidal Peña). Madrid: Alianza.

Zambrano, María (2005). El hombre y lo divino, Madrid: Fondo de Cultura Económica.

Recibido: 3/11/2008

Aceptado: 25/12/2008 